\title{
Love and Justice: a Paradox?
}

\author{
Anca Gheaus, Universitat Pompeu Fabra
}

\begin{abstract}
Three claims about love and justice cannot be simultaneously true and therefore entail a paradox:

(1) Love is a matter of justice.

(2) There cannot be a duty to love.

(3) All matters of justice are matters of duty.

The first claim is more controversial. To defend it, I show why the extent to which we enjoy the good of love is relevant to distributive justice. To defend (2) I explain the empirical, conceptual and axiological arguments in its favour. Although (3) is the most generally endorsed claim of the three, I conclude we should reject it in order to avoid the paradox.
\end{abstract}

\section{Introduction}

"All you need is love" sang the Beatles, and their song became a best hit. They overstated their case; we need ${ }^{\mathrm{ii}}$ a lot more in order for our lives to go well: clean air and water, food and shelter, reasonable levels of safety and social interaction that has little to do with love. Nor is love what we most urgently need: one or several of the things above have priority because we can survive without love, but not without them. Yet, like Beatles fans, and many others, I assume that giving and receiving love is constitutive of (even minimal) flourishing for the vast majority of people. We can, especially as adults, bridge periods of time without any love and without being, for this reason, severely harmed. But we typically cannot have good lives without ever experiencing some love in relationships with other people.

"Love" is very frequently used and yet notoriously difficult to define. Philosophers disagree on what it is, and in this paper I do not commit to a particular definition. Whatever else it may involve - whether a disposition to be affectionate towards, care for, or pay special attention to, the beloved - personal love is motivated by the individuality of the beloved ${ }^{\text {iii }}$, given at least in part out of inclination, and, at least to some degree, spontaneously. As opposed to relationships in which we 
are less personally invested, in loving the lover's own well-being is not independent from the wellbeing of the beloved: if the beloved's life goes badly for her, the lover's life also goes worse, in some sense and for this very reason. In virtue of these features, personal love is a confirmation of the beloved's value, and this is its non-instrumental contribution to how well one's life goes. Caring for someone is a disposition to benefit that person, disposition which is not necessarily motivated by the individuality of the cared-for and that could, instead, be entirely motivated by duty. The distinction between love and care is important for the argument in the third section. The main claim of this paper is that the non-instrumental value of personal love poses a serious challenge to the way in which we think about distributive justice.

Three plausible claims about love and justice cannot be simultaneously true and therefore entail a paradox. The last two are generally, although not universally, accepted. The first is more controversial but, I hope to show, follows from some widely endorsed conceptions of justice. This section briefly introduces the claims and subsequent sections discuss the arguments in favor of each claim. The first claim is about the relationship between justice and love:

(1) Love is a matter of justice.

This claim can be plausibly interpreted in two different ways:

1.1. The relative extent to which people enjoy the good of love is a matter of fairness, and therefore of justice as (luck egalitarian) fairness.

or

1.2. People need to be loved at least sometimes and to some degree in order to lead sufficiently good lives, therefore love is a matter of justice as sufficiency.

Love has significant, and non-instrumental, non-substitutable and widely recognised value. (1) follows directly from factoring this belief about love's value into some of the currently dominating conceptions of distributive justice: luck egalitarianism and sufficientarianism. The core claim of luck egalitarianism is that it is unfair, and thereby unjust, for some to be worse off than others through no fault or choice of their own. This is a claim about the correct pattern of 
distribution, and luck egalitarians disagree with respect to the metric of distribution. Here I assume that love is constitutive of wellbeing, but that it can also be conceptualized as a resource, as a form of advantage or as a capability. But one does not have to be a luck egalitarian to endorse that love is a matter of justice. Sufficientarians believe it is unjust when some people lack what they need for a sufficiently good life. If love is necessary for a sufficiently good life, sufficientarians, too, ought to see it as a matter of justice. I do not discuss whether love poses the same kind of challenge to another influential theory of justice, namely John Rawls'. However, if the non-instrumental good of love is necessary in order for individuals to acquire self-respect - which, according to Rawls, is the most important primary good - the scope of my argument is even wider. This is not implausible, assuming that as children we need to be loved in order to acquire a positive conception of the self and the motivation to develop our talents (Liao 2015: 79-85.)

A few caveats are necessary. Some of you will find the claim that love is a matter of justice deeply implausible because you think that feasibility constraints determine the conten of justice. It is difficult to imagine that we could ever bring about a fair distribution of the good of love and therefore, if what is a matter of justice depends on what is feasible, love cannot be a matter of justice. Yet, the position that feasibility partly determines desirability comes at significant theoretical and practical costs (Gheaus 2013). By contrast, I assume that the answer to the question of what is a just distribution of benefits does not conceptually depend on what is feasible (Cohen 2009). Feasibility matters for deciding who, if anyone, ought to bring about a particular distribution but the question of what is a just distribution must be decided prior to deciding whether it is feasible to bring that distribution about. I will return to the issue of feasibility and love as well as to the question concerning the concept of justice in the discussion of the second and third claims respectively. The second caveat follows from the first: that love is a matter of justice need not directly entail any claim about the role of the state, or of any other agent of justice, in bringing about a fair distribution of the benefits of love. (Indeed, this paper is not committed to any view on which agents have reasons of justice.) 
The second claim is about love, that:

(2) There cannot be a duty to love.

It is not entirely up to us whether, whom and how much we love. Moreover, while we can and, as I will show, ought to - try to bring about the conditions under which love is likely to be forthcoming, we cannot ultimately control its evolution since, as a conceptual matter, love must be partly motivated by the individuality of the beloved.

Recent attempts to deny (2) aim to prove that love can be controlled. I shall explain why such attempts fail to address the problem that a duty to love is an absurdity. If love's unique value depends on some measure of spontaneity in giving it then no amount of empirical research indicating that we can control some of the conditions of our loving can establish the existence of a duty to love. To better see this, I shall discuss the likely loss experienced by someone who is at the receiving end of mere love-like behavior when what she needs is genuine love.

The third claim is also about justice. It is generally accepted that any injustice entails rights violations, and that for a right to exist there must be correlative duties. Therefore, justice is believed to be conceptually connected to duty. The third fundamental claim I discuss is:

(3) All claims of justice are conceptually connected to claims of duty.

This claim is not inconsistent with the above-announced methodological commitment concerning justice and feasibility. One may be able to give examples of unfairness that cannot be rectified and which (if ought implies can), no agent has a duty to rectify. However this does not in itself indicate that "justice" in such examples is conceptually disconnected from duties. Presumably, if it became possible to rectify the injustice in case, some agent would acquire a duty to do so. Even if justice does not depend on feasibility, while actual duties do, justice still seems to depend on duties that would obtain in more favorable empirical circumstances - or, as I shall call them here, on counterfactual duties. As G.A. Cohen $(2009,252)$ put it, "we find fundamental justice within claims of the form: if it is possible to do A, then you ought to do A."

Claims (1), (2) and (3) are explored and defended in the next three sections. 


\section{Claim (1): Love is a matter of justice}

Here I am concerned with love in general, rather than with any particular kind such as romantic, companionate, parental or filial love. I often use illustrations drawn from parental love, which are best suited to make the case that the extent to which individuals enjoy love is a matter of justice. Yet, the scope of the paper goes beyond parental love. Love as understood here is personal, which means that it is directed at, and responsive to, the individuality of the beloved rather than being directed at, and responsive to, what particular individuals have in common with wider groups of individuals, as is the case with Christian love, Buddhist love, or love for humanity. Being personal in this sense, love is also partial: we love some individuals and not others. On most interpretations, personal love involves responding to the individuality of the beloved with a robust disposition to care for or be attached to that individual. But the present analysis is equally relevant to the alternative view that love consist in an ability to pay special attention to the beloved. I also assume that, precisely because it is directed at the individuality of the beloved, the attitudinal dimension of love involves an element of spontaneity which is constitutive to how love is valuable for the beloved.

Two arguments support the conclusion that being loved and, perhaps, being able to love, are matters of justice. If at least one of them is successful, claim (1) can be established. The first argument assumes luck egalitarianism:

Argument 1.1.

(a) It is unfair, and thereby unjust, for some to be worse off than others through no fault or choice of their own (luck egalitarianism).

(b) Being loved significantly contributes to how well a person's life goes.

(c) Love is, to a significant extent, a matter of brute luck.

Therefore 
(1) Love has to be taken into account when assessing the justice of a distribution, and, in this sense, it is a matter of justice.

Although popular amongst contemporary philosophers, luck egalitarianism is not endorsed by everybody. A second argument to the same conclusion assumes that justice requires only that which makes lives go sufficiently well; its more modest upshot is that being loved and able to love sufficiently are matters of justice:

\section{Argument 1.2.}

(d) Justice requires that people have what they need in order to lead sufficiently good lives (sufficientarianism).

(e) People need to be loved and to be able to love at least sometimes and to some degree in order to lead sufficiently good lives.

Therefore

(1) Love is a matter of justice.

Argument 1.1.

(a) It is unfair, and thereby unjust, for some to be worse off than others through no fault or choice of their own (luck egalitarianism).

In Cohen's $(2009,7)$ words, "an unequal distribution whose inequality cannot be vindicated by some choice or fault or desert on the part of (some of) the relevant affected agents is unfair, and therefore, pro tanto, unjust". This is an influential conception of justice and its fundamental intuition about fairness is shared by philosophers who cannot be properly described as luck egalitarians. It is for instance present in Rawls' understanding of justice, at least to the extent to which the moral goal of a theory of justice is to come up with a conception "that nullifies the accidents of natural endowment and the contingencies of social circumstance as counters in the quest for political and economic advantage" (Rawls 1972, 5). 
(b) Being loved significantly contributes to how well a person's life goes.

"Nobody has ever loved me" is one of the gravest complaints that one can make about their life. Similar - or perhaps worse - is "I am not able to love anybody" that love cannot be substituted by the enjoyment of other goods. Enjoying some kind of love to some degree seems to be a significant constitutive part of a person's subjective and objective wellbeing.

This belief is supported by anecdotal evidence and testimonies of people who identify loving family and friendship relationships as the, or at least one of the, most important goods contributing non-instrumentally to their well-being; this led some philosophers to argue that in a just society people would enjoy loving relationships equally (Lynch et al. 2009). Love is also instrumentally valuable to creating agency: a vast feminist and psychological scholarship defends the importance of early loving relationships for becoming properly socialised, and moral, individuals (Ruddick 1989; Held 1993; Hollway 2006) - characteristics which, in turn, are necessary conditions for leading a good life.

If it is true that being loved, especially early in life, contributes to the ability to value oneself as a unique individual, to become aware that one has intrinsic value and to acquire basic inner resources such as confidence and resilience, then enjoying loving relationships is what philosophers Jonathan Wolff and Avner De-Shalit (2007) call a "fertile functioning" - that is, a desirable state that increases one's likelihood to achieve additional desirable states.

Different luck egalitarians identify the metric of justice as either welfare, or capabilities or resources. The non-instrumental value of love is plausibly important enough to be necessary for a fully flourishing life - and hence love is directly relevant to theories that identify welfare, or opportunities for welfare, or capabilities, as the metric of justice. Whether or not one's need for love is met also shapes that person's opportunities for other goods; because love also has instrumental value, it can be plausibly seen as a kind of resource and therefore relevant to resourcist conceptions 
about the metric of justice. Love cannot, however, count as part of the metric of justice on a monistic resourcist view that identifies money as the relevant resource.

(c) Love is to a significant extent a matter of brute luck.

Perhaps, as adults, we can be held responsible to a great degree for the good as well as for the bad that love brings us to the extent to which we can choose the people with whom we relate. Yet, it is obvious that much of the circumstances of our relationships are not under our control - such as the conditions in which we meet those we love or lose them because they die. More importantly, to many of us it is somewhat mysterious what elicits our affection, desire, tenderness, longing, curiosity and attention. It is far from obvious that one can decide to love certain individuals and not others, even if the latter would make, according to one's own judgment, perfect recipients of one's love (Rainbolt 2016); nor is it possible to control who loves us. Further, we have little control over continuing to love another person or securing their continued love.

The claim that love is a matter of brute luck is most difficult to dispute if we think about children and parents: children do not have any choice of who their parents are and how well their parents love them.

From (a), (b) and (c) it follows that: (1) Love is a matter of justice.

Many are skeptical of luck egalitarianism; its critics worry that it is impossible to implement its ideal of fairness and some point out that even trying to implement it would have unacceptable consequences for personal relationships (Lazenby 2010). They conclude that luck egalitarianism is best seen as a theory which, on its own, has little action-guiding potential. This conclusion does not undermine the point of this paper. It is consistent with believing that, if we could shape the world such that nobody's life went worse than others' for lack of love out of no fault or choice of their own, it would be a requirement of justice that we do it. 
More radical critics believe that luck egalitarianism is implausibly describing as unfair, and pro tanto as unjust, too much of what we usually attribute to unavoidable unfortunate circumstances - and, indeed, the way in which love upsets fairness is likely to raise this objection. A widely endorsed alternative to luck egalitarianism is the view according to which the aim of justice is to ensure that everybody has enough to lead a sufficiently good life. In particular, according to the defenders of an increasingly influential view, an adequate understanding of justice should instead focus on the relationship between citizens, aiming to eliminate obvious forms of injustice such as exploitation, domination, oppression, exclusion and marginalisation (Young 1988; Anderson 1999; Scheffler 2003). Many of these critics, who call themselves relational egalitarians, think that the real aim of justice is to ensure that everybody is sufficiently functional and socially included. Even if the aim of justice is to establish egalitarian relationships rather than some kind of distributive equality, just societies will not allow their members to fall below a certain threshold of well-being. I argue that various types of sufficientarians all have reason to endorse the second argument to the conclusion that love should be regarded as a matter of justice:

\section{Argument 1.2.}

(d) justice requires that people have what they need in order to lead sufficiently good lives (sufficientarianism).

Sufficientarianism is a modest standard of justice. However, those who reject pattered conceptions of justice, such as libertarians, deny that even minimal well-being is due to people as a matter of justice. For them, the overall argument of this paper is a reductio of the particular conceptions of justice to which I appeal.

(e) people need to be loved at least sometimes and to some degree in order to lead sufficiently good lives. 
Needs of the non-instrumental, morally significant, kind are best understood in relation to harm. According to David Wiggins' $(1998,10)$ definition of intrinsic needs, I need X "if it is necessary, things being what they actually are, that if I avoid being harmed then I have X"v. Another feature of intrinsic needs is that they are not chosen, and that individuals cannot simply decide not to need what they need.

It then seems plausible that all people need to be loved: much time, energy and other resources are spent in the quest for love and, when love is found it never seems to appear futile (unlike other goals that we pursue relentlessly.) According to people's own testimonies, lives devoid of any love or hope for future love are often very miserable for this reason. And it is not up to people to decide that they can do without love (although it can be up to an individual to decide they can do without a loving relationship with a particular individual.) This is a stronger claim that (b) while still weaker than the Beatles' slogan.

The most charitable interpretation of Beatles' slogan - which will not convince everybody is that we have a very important need for love and that love cannot be substituted. Then, love's absence entails significant harm and lives can hardly go sufficiently well if entirely deprived of love. This is vividly illustrated in the case of parental love: even those who are skeptical that adults need love in order to have sufficiently good lives will likely accept that children's lives cannot go well enough in the absence of love from an adult. For this reason, Matthew Liao $(2006 ; 2015)$ and Norvin Richards (2010) have recently defended the controversial position that parents have a duty of justice to love their children and children have a correlative right to be loved. Both argue that parents are responsible to ensure that their children reach an adequate level of well-being and that their children's developmental needs are met, and rely on empirical literature to show that none of these goals can be achieved in the absence of parental love. According to Liao: "Studies of children in institutions found, for example, that children who did not receive love but only adequate care became ill more frequently; their learning capacities deteriorated significantly; they became decreasingly interested in their environment; they failed to thrive physically by failing to gain 
weight or height or both; they suffered insomnia; they were constantly depressed; and they eventually developed severe learning disabilities" (2006, 423).

Further, some philosophers and psychoanalysts writing on recognition draw on a Hegalian tradition to claim that love, in particular parental love, plays a central role in the formation of agency - in shaping personhood and autonomy (Benjamin 1988; Honneth 1992). For example, it has been claimed that love is necessary for self-trust (Anderson and Honneth 2005). If having experienced love is crucial for autonomy and personhood - a claim also endorsed by the feminist ethics of care, at least when applied to parental love (Ruddick 1989; Held 1993) - then its absence can easily undermine our standing as political equals. Therefore, relational egalitarians as well as other sufficientarians have reason to be concerned with its distribution.

As Liao's critics noted (Cowden 2012), empirical studies only show that good emotional relationships between children and their caregivers are essential for children's flourishing and that in their absence children's development is seriously impaired. But we do not know which aspect of these relationships is crucial for flourishing. As far as the empirical studies are concerned, one may conclude that children's flourishing is entirely due to the behavioural aspects of parental love, such as expressions of affection towards their children, attentiveness to their individual needs, quality time spent together and parents' stance of partiality towards their children. How much does it matter to children that such behaviour is motivated by their parents' partial response to their children's individuality? It may be very difficult to devise empirical investigations to establish this. First, the emotions of love are very difficult to capture, define and measure. Second, it is very unlikely to encounter sufficient cases of the above-mentioned behaviour unsustained, on the long run, by genuine love, that is by responsiveness to the individuality of the child. While I do not think that the empirical evidence gives (or, possibly, could give) conclusive support to the claim that responsiveness to the individuality of the child is a significant part of what makes love so important for children, I think we have nevertheless good reason to give credence to this claim. The good of personal love is not reducible to the good of beneficial actions. Because when done out of love 
these actions are motivated by the individuality of the beloved, love is an affirmation of the value of the beloved - a point to which I return below. And, plausibly, it is love's affirmation of the beloved's value that gives love an important role in the formation of autonomy and personhood ${ }^{\text {vi }}$.

From (d) and (e) it follows that, especially during the formative years of childhood: (1) Love is a matter of justice.

The sufficientarian argument makes no reference to personal responsibility or individual choice. On the one hand, obliterating the issue of personal responsibility makes the sufficientarian argument a generous frame for understanding the relationship between love and justice: if somebody's life is entirely devoid of love due to that person's choices, and as a result an intrinsic need of that person is unmet, this situation would still count as unjust according to the sufficientarian account ${ }^{\mathrm{vii}}$. Unsurprisingly, one of the most influential sufficientarian theories of justice, which identifies capabilities as the metric of justice, explicitly lists a capacity to love and be loved amongst the relevant capabilities (Nussbaum 2006). Drawing on psychological literature, Liao (2015) argues that the acquisition of these capacities requires that one has experienced parental love.

On the other hand, the second argument is less demanding, as it need not describe as unfair or unjust all inequalities in how much and how well we are loved (and for which we are not responsible). If luck egalitarianism is true, then all inequalities in love that are not due to our own responsible choices are unfair unless they are compensated for. In practice, this would certainly amount to detection of massive injustice in the world. On most sufficientarian accounts there is no injustice in the fact that we are unequally loved as long as we all receive enough love for our lives to go well.

To illustrate the different implications of arguments one and two, the first deems a situation where parents love some of their children more as unjust while the second deems it just as long as all children receive sufficient love. 


\section{Claim (2): There cannot be a duty to love}

Kant formulated an influential endorsement of (2): "Love is a matter of feeling, not of willing, and I cannot love because I will to, still less because I ought to (I cannot be constrained to love); so a duty to love is an absurdity” Kant $(1996,161)^{\text {viii }}$. Recently, however, several philosophers have argued that children have a right to be loved and that parents have a duty to love their children (Liao 2006, 2015; Richards 2010; Ferracioli 2014). Liao, who defended a right to be loved, and Luara Ferracioli, who defended a duty to love - both driven by the importance that love has for children's wellbeing and development - usually read the Kantian position as being about what people can and cannot do - so, ultimately, as grounded in an empirical claim (which they reject). The same interpretation of Kant's position is implicit in Liao's critics and other philosophers who draw on Kant in order to deny that there can be rights and duties to love (Brake 2011; Cowden 2012). I will therefore first discuss:

Argument 2.1.:

(f) We cannot fully control whether or not we love.

(g) “Ought” implies "can".

Therefore:

(2) There cannot be a duty to love.

As I will explain, it is difficult to deny (f). But even if (f) was false, there is a philosophically more interesting, and overall more plausible way of understanding Kant's position as being not about the limits of individuals' abilities - and hence about an empirical matter - but about what counts as "love" - and hence about a conceptual matter. On this second reading, if we could fully self-induce all the dispositions and emotions that we typically identify as "love" we would nevertheless fail to love, because, by assumption, love must be at least in part caused by something outside the loverby the beloved. (Kant's formulation, at least in translation, appeals to human ability, yet concludes 
that a duty to love is absurd rather than impossible. It therefore remains ambiguous between an empirical and a conceptual interpretation.)

The next argument draws on Philip Pettit's recent account of love as a robustly demanding good to explain why love-like behavior that does not respond to the individuality of the beloved is conceptually different from love. A conceptual argument about the impossibility of a duty to love, however, would be of limited interest if it was merely semantic. I compare genuine love to love-like behavior that fails to be adequately motivated by the individuality of the beloved and claim that the intrinsic value of the former comes from the fact that it is given out of inclination and with a measure of spontaneity. Therefore, we have good reason to employ a concept of love that makes a duty to love absurd. One may, and possibly should, cultivate certain dispositions - including dispositions to notice, appreciate and become responsive to others - that make genuine love more likely. But the intrinsic value of love is realised only when inclination, and hence spontaneity, play a role in loving. This is:

Argument 2.2.:

(h) People need some affection, care or attention given spontaneously, out of inclination.

(i) Therefore the affection, care or attention resulting exclusively from one's self-controlled behaviour would not meet the specific need for love.

(j) Therefore meeting the need for love cannot be a matter of duty. Therefore:

(2) There cannot be a duty to love.

I now move on to defend these arguments.

\section{Argument 2.1.}

(f) We cannot fully control whether or not we love.

As noted above, love cannot be entirely a matter of volition: we cannot bring ourselves to love other people just because we want to. This is a familiar claim, put forward by philosophers and non- 
philosophers alike. From Kant to Jane Austen, there is a consensus that genuine attachment cannot be fully commanded. Since love is responsive to the particularity of the beloved, it involves the individual taste of the lover and her selective sensitivity and attention - features that we can cultivate but not entirely control. Suppose Jane's love for Jill may be renewed every time Jill displays her quirky, shy or tender sense of humor; the fact that she notices and appreciates this feature in Jill and not in others (at least not in a love-conducive way) is not entirely up to Jane. Most of us believe we are not able to engineer the partiality that defines personal love.

While the more familiar illustrations of (f) come from romantic or companionate love between adults, the love of parents for their children can also illustrate this point. Parents who, in spite of their best efforts, cannot love a particular child (for instance, because they are themselves struggling with depression), or cannot love all of their children equally, are not unheard of. This last example shows why (f) represents a problem for realising fairness with respect to love on a luck egalitarian understanding of justice. If you are less loved than your siblings through no fault of your own, and if being less loved than your siblings has a negative impact on your opportunities, then unequal parental love entails unfairness. And if love is important for justice because we have an intrinsic need for enough love, then parents' inability to love a child enough will create injustice even according to the more modest principle of sufficiency.

The idea that there cannot be a duty to love has been contested, with respect to both parental and romantic love. Defenders of a duty to love children ground their argument in the importance of love for the beloved's wellbeing to argue that love is owed to children as a matter of justice (Liao 2006, 2015; Richards 2010). They also argue that love is, to some extent, under our control because we can cultivate loving dispositions towards individual people. Iddo Landau and Matthew Liao illustrated ways in which individuals can take action that is very likely to evoke, maintain or renew marital and parental love (Landau 2004; Liao 2006). These arguments are persuasive but limited. As their critics show, individuals can achieve only that much success in their attempts to self-induce affection towards or caring for, a particular individual (Brake 2011; Cowden 2012; Rainbolt 2016). 
Affection and caring (as well as special attention) respond to some of the qualities of the beloved; this claim need not presuppose the controversial view that we love people because of their qualities, but the more modest one that sufficient change in certain qualities of the beloved can challenge, and sometimes destroy, love (Brake 2011).

The claim that love cannot be commanded can be read as an empirical truth. But what if we were able to overcome the typical limitations of controlling love by making love impervious to changes in the beloved - what if we were able to create "the love drug"? A number of philosophers have recently defended the use of neuro-enhancements to improve love (Nyholm 2015). Even if the love drug was available, however, its advocates suggest its use as a consolidator of already established love. None defends the claim that we could or should make available a love drug that makes it possible to assign, to each individual in need of love, someone to provide the affection, care or attention they could not provide in the absence of the drug. Nor does anyone suggest that love drugs could or should be used to ensure that everybody enjoys love equally. Defenders of the claim that we should make available a love drug propose it as a solution for expanding the scope of control we have over love, rather than bring it entirely under our control. As I show below, this is wise.

(g) Ought implies can - one cannot be morally required, even less be under a duty to, do something one cannot do.

The most uncontroversial interpretation of this fundamental, widely endorsed principle, is that an agent is not violating any duty by not doing what she cannot do - no matter how much value that action would realise, should she able to do it.

One cannot logically exclude the possibility of a world in which, serendipitously, everybody is sufficiently or equally loved. And there might be many things we can do in order to move closer to this world by giving people the time and leisure to be with and focus on others, educating them to cultivate loving dispositions and relationships, containing mental and emotional disorders and 
mitigating their effects. However, if the present argument is correct, our intentional action and hence duty will have to stop at doing whatever it takes for love to flourish for all - for people to spontaneously respond with love to some others. Yet, all this amounts to is a (collectively held) duty to enable love.

From (f) and (g) it follows that: (2) There cannot be a duty to love.

\section{Argument 2.2.}

The worry concerning drug-induced affection, care or attention is that, being drug-induced, they would not be responsive to the individuality of the beloved. This amounts to a conceptual claim: that love over the creation of which the agent has full control - and which therefore could be given out of duty - is not really the partial, personal love that is so important to our wellbeing. If who you are plays no role in explaining my love for you, I may feel for you - say - humanitarian, or Christian, love but not personal love.

Everyday uses of "love" tend to involve, conceptually, that love cannot be given at will. The non-volitional element of love explains why we believe that attempts to buy or sell love, or to extract it by force are not merely doomed to failure, but confused: If I were to report success in my attempt to fly without the help of a machine you would think that I am deluded or lying. But if I were to report success in buying someone's love you should suspect that I fail to grasp the meaning of "love". The motivation for loving someone - the process through which we get to respond with love to a particular individual - is part of what defines the complex of dispositions and emotions that we call "love". So, for instance, if it turns out that we have been badly mistaken in our believes about a person we love, or that we have been drugged into feeling affection for her, we would think we don't actually love her even if our subjective experience is identical to that of genuine loving. In the case of being drugged we may think that we are in the grip of an obsession rather than experiencing the genuine attraction of love. 
Philosophers usually follow the common-sense use of "love" in this respect. To take a recent example, Pettit (2015) defends an account of love as a good which is robustly demanding because it involves a stable disposition to care for the beloved (across a certain range of possible world) and also because this disposition must be particularized or relational, that is triggered by the individuality of the beloved. Unlike dutifulness, which an agent should be able to trigger independently from who the particular identity of those to whom she owes duties, the dispositions that are constitutive of the love for a particular individual can only be triggered by that particular individual. Or else, it fails to count as personal love.

So (2) is best understood as a conceptual claim: for affection, care or attention to count as a genuine expression love, they should be responsive to the individuality of the beloved, and hence, at least to some extent, outside the lovers' control. One may insist that this is a semantic, rather than a normative, point. Independent of what we call "love", the relevant question seems to be whether we could achieve a fair distribution of what we find valuable about love, by better training our emotions and behavior or by using a "love drug" that induces love-like behavior. If we had the means to control love-like behavior, would a duty to do so achieve a just distribution of all that is valuable in love? I believe not, and here is an argument to that conclusion:

(h) People need some affection, care or attention given spontaneously, out of inclination. 
What is the value of personal love? There are situations in which it seems, intuitively, that our yearning for personal love is so great that we cannot but feel disappointed when, instead of it, we receive mere dutiful love-like behaviour - even when the latter is as such praise-worthy. Consider Michael Stocker's example of the hospital visit: “[S]uppose you are in a hospital, recovering from a long illness when Smith comes in. You are so effusive with your thanks and praise that he protests that he always tries to do what he thinks is his duty, what he thinks will be best. You at first think he is engaging in a polite form of self-deprecation. But the more you two speak, the more clear it becomes that he was telling the literal truth: that it is not essentially because of you that he came to see you, not because you are friends, but because he thought it his duty, perhaps as a fellow Christian or Communist or whatever, or simply because he knows no one more in need of cheering up and no one easier to cheer up.” $(1976,462)$

This story illustrates an important need that personal love fulfils: that some people display partiality $^{\text {ix }}$ towards us - perhaps what Kant has called pathological inclination. To enjoy the partiality of a lover is part and parcel of the good of being loved by that person. Moral philosophers are usually interested in how partiality hinders our ability to comply with moral demands, which makes partiality regrettable. However, to the extent to which partiality is constitutive of personal love it also represents an important good. Being sometimes on the receiving end of loving partiality seems crucial for feeling valued as an individual. Some think that personal, and thereby partial, love is sufficiently important to override reasons of duty in some cases: Bernard Williams $(1981,18)$ described the person who wonders whether it is morally acceptable to save the life of his wife, rather than that of a stranger, as having "one thought too many". Now, in cases where rescuers do not have one thought too many, their beloved may have two reasons to rejoice: that they were rescued, but also that they are so valuable to their rescuer that considerations of duty did not enter the rescuer's deliberation. 
Going back to the example of children's need to be loved by their main care-givers, it is indeed easy to make sense of a child complaining that the care, affection, attention and time she receives from her parents are given entirely out of duty. This child has reason to feel that something very important to her is missing. She might feel, for instance, that she is treated impersonally - that the affection she receives has nothing to do with her individuality. More generally, when people display love-like behavior towards us, but we suspect that they are acting out of mere duty, we may feel valued as human beings, but certainly not as particular individuals, and we have reason to regret the later. Personal love seems unlike any other good the distribution of which can be a matter of justice. When individuals receive due amounts of, say, food by agents whose behavior is entirely motivated by duty, there is no complaint left with regard to food distribution. But when they are at the receiving end of affectionate, caring, attentive behaviour entirely motivated by duty there remains a complaint: these individuals do not enjoy the full good of love.

What is the good of personal love such that one fails to provide it if one's love-like behavior fails to be, at least in part $^{\mathrm{x}}$, motivated by the reality of the beloved? It is plausible that personal love is so important to the beloved because it is an affirmation of her value. Some believe that love is an appraisal of the value of the beloved (Velleman 1999), others that it is a bestowal of value on the beloved (Singer 1994). In either case, in love etiology as well as phenomenology count. Love-like behavior that fails to be caused by the beloved cannot deliver this good. As Sven Nyholm (2015, 197) puts it: "Love is ... a sort of confirmation that we are, as we might put it, 'lovable' in the sense of being able to inspire or call forth such dispositions in another (namely, the lover). Part, but not the whole, of what our lover gives us in loving us, in other words, is this confirmation of us as really being able, or having the power, to inspire loving devotion in another."

Personal love can give such confirmation because, in being loved by someone, the beloved directly contributes to her lover's wellbeing. In order to fully satisfy a person's interest in being loved it is necessary that the lover's own interest is, to some extent, involved in the loving relationship. Think, for instance, of a parent playing with her child: because she loves the child, the 
parent takes particular pleasure in watching the child have fun and this - the parent's genuine delight - is part of what satisfies the child's need for love. Or think about what it means to grieve for a loved one who died, as opposed to regretting the death of someone about whom you merely cared. In the latter case you may be sorry for all the good things that person will be missing out on, but not for yourself. By contrast, grieving for someone you love means to also perceive their death as a loss to yourself - to regret not only that the deceased cannot, say, laugh with and talk to other people anymore, but also that you cannot laugh with them and talk to them anymore.

If one accepts step (h), one will accept that:

(i) Therefore the affection, care or attention resulting exclusively from one's self-controlled behaviour would not meet the specific need for love.

It follows that:

(j) meeting the need for love cannot be a matter of duty.

Therefore:

(2) There cannot be a duty to love.

This last argument supplements the conceptual point with an axiological one: it states that "love" given entirely out of duty would not be love and that we have good reason to hold on to this concept of love because we need affection, care or attention that spring from our lovers' partiality towards us; this requires some degree of spontaneous inclination towards us. If our emotional needs were more modest - if we could do with affection, care or attention of an impersonal, impartial kind, then, perhaps, a duty to meet this need could exist.

Note that, if the argument of this section is correct, the familiar danger of conflating issues of feasibility with issues of desirability is not present in the case of love. A crucial test for deciding whether something is a matter of justice is to ask: "If we could bring that thing about, would we have a duty of justice to do it?" For instance, on purely luck egalitarian grounds, if we could, at no costs, shuffle eyes between the people with perfect sight and the blind, such that everybody ends up with one functional eye, we should do it. The test cannot be run with love if it is conceptually true 
that there cannot be a duty to love. If (2) is true, whatever one thinks about the relationship between feasibility and justice, one will want to reject the claim (1) that love is a matter of justice if one subscribes to claim (3) that all claims of justice are conceptually connected to claims of duty. It is to this last claim that I am now turning.

\section{Claim (3): All claims of justice are conceptually connected to claims of duty}

The third claim is almost universally endorsed. The most straightforward way of interpreting it is to say that something can be matter of justice only if it is some agent's duty to bring that thing about. This interpretation would make claim (3) a good candidate for rejection, and rejecting claim (3) would dissolve the paradox.

It seems false that something cannot be a matter of justice if nobody has a duty to do something about it: sometimes there is no agent whose duty it is to prevent or rectify a particular injustice, without this being a reason to think that the state of affairs in case is just. Examples include past injustices whose victims and perpetrators are dead such that no rectification is possible, nor is there any agent who may have a duty to compensate. (Imagine, in addition, that no living individual either benefits or suffers from the past injustice.) Assume there have been cases of one group enslaving or destroying another group that happened so far back in the past that no living person's life is affected by it. In these cases some duties existed - and have been violated - in the past. One may speak, here, of past duties.

There is a second type of case when something can be a matter of justice - at least according to an account of justice that is insensitive to feasibility constraints - and in which there are no duties, present or past. Think for instance of natural catastrophes that cannot be prevented or foreseen, and that cause irreversible damage. Or, similarly, of people dying very young from unpreventable and incurable diseases. Since the victims are dead, there are no duties of compensation. In all these situations some people's lives went (much!) worse than others', through no choice or fault of their own. In these cases, however, there exist what we might call 
counterfactual duties: if an agent could have done something for the victims that agent ought, as a matter of justice, to have done it.

Therefore, the more precise interpretation of (3) is: "For something to be a matter of justice there should be a conceivable duty to bring that thing about." That is, matters of justice are conceptually connected to duties: present, past or counterfactual.

Yet, unless (2) is false, in the case of love there are no duties - present, past or counterfactual. The predicament of the person who needs love, and whose life goes worse than others' because she lacks love is similar to that of people caught in a natural catastrophe which could not be averted in that it is not the result of human action and could not be avoided by human action. But here the similarity stops. If one could save the victim of a natural catastrophe, one ought to do it; by contrast, no change in the feasibility constraints that agents may face could generate a duty to love.

This is not to deny that, sometimes, a failed duty is part of the causal history leading to the lack of love. One illustration of this claim is the situation of large numbers of children who grew up without parents in the 1980's and 1990's on Romanian streets. This situation was directly caused by policies banning contraception and abortion, and by the Romanian state's failure to live up to its duty to provide adequate care for abandoned children. Presumably, in the absence of these policies and failures of justice some of the children deprived of parental love would not have been born, and many of those who have been born would have enjoyed adequate parental love. But certainly not all maldistributions of love flow from past failed duties: there is no reason to think that, had the Romanian state behaved justly towards all its children, they would have all enjoyed equal, or even enogh, love.

\section{A paradox?}


Unless one of the three claims can be shown to be false, a very unsettling conclusion follows: not merely that perfect justice is not feasible - something few would dispute - but that we cannot think about love and (at least some kinds of distributive) justice together in a consistent way. Which of the three claims should then be rejected?

I believe we should not abandon the major premises supporting (1) easily. In particular, abandoning luck egalitarianism would entail accepting that sometimes unfairness is irrelevant to considerations of justice, and this is a high theoretical and possibly practical ${ }^{\mathrm{xi}}$ price. A better way to resist (1) would be to show that love as defined here is an important, but not unique, form of validation of our individuality. This is a theoretical possibility, but the burden of proof seems to be on whoever thinks that something other than personal love can deliver what I identified here as its non-instrumental good.

I also believe, for reasons discussed at length in the second section, that we should continue to endorse (2). (2) could be rejected by showing that the good of love whose distribution is a matter of justice can be realised even when love-like behaviour is not motivated by the beloved's individuality. This way out of the paradox is to deny that we actually need the kind of affirmation of our value that personal love gives us. Perhaps the importance we attach to our value as unique individuals is misguided. One may think that individuality itself is overrated and that human beings would be better off if, instead of love, they should seek impersonal and impartial affection (such as, for instance, Buddhist love or a secular version of Christian love). This possibility goes very much against the grain of our culture, which is deeply attached to the value of individuality, but possibly more coherent with alternative ways of valuing and therefore not impossible to make sense of. It is beyond the scope of this paper to examine whether we should let go of the value of individuality. If this were the case, then a different kind of "love" would be a matter of justice - a kind of love that is not personal and therefore is more amenable to control by the lover without loss of significant value. Some readers might be happy with this conclusion. 
The wide acceptance of the second claim, that love cannot be a matter of duty, explains why the very idea of having a duty to love is prima facie implausible. Yet, there are good reasons to believe that there is at least a duty to try to create the conditions for everybody to receive sufficient love. While duty does not require that everybody is loved, it does require that we try and create the social conditions conductive to flourishing loving relationships which exclude as few individuals as possible. There may be various ways of promoting inclusive loving relationships. For example it is plausible that we have a duty of justice to create the social conditions that allow as many children as possible to receive adequate, loving care from adults (Brighouse and Swift 2014). Kathleen Lynch, John Baker and others (2009) argued that personal love is one important metric of justice for children and adults alike, and argued for policies that would facilitate a more egalitarian enjoyment of loving relationships.

Note that recognising a duty to create the social conditions in which loving relationships thrive, including as many people as possible is coherent with the claims (1) that love is a matter of justice and (2) that there cannot be a duty to love. We can imagine, and hope, that, were we to fulfil the duty to realise the conditions under which love could flourish, love would indeed be enjoyed to a more equal extent by different people - and, that, at the very least, nobody's life would fall below the sufficiency threshold due to a lack of love. But such a lucky outcome would, however, not dissolve the paradox, since the paradox does not stem from an issue of feasibility but from one of conceivability. Unlike a duty to love, a duty to try to love is conceivable. Yet, even full compliance with such a duty cannot ensure that the non-instrumental good of love as defended here is delivered and therefore that full justice is realised. What we ultimately need is to be loved, not merely to live in a society organised to promote inclusive love relationships. And therefore one cannot reduce the claim (1) that enjoying love is a matter of justice to a less demanding claim that (1*) Attempts to create loving relationships is a matter of justice.

Another answer to the question of love and justice that would fail to dissolve the paradox is to say that, in principle, those who do not enjoy their fair share of the non-instrumental good of love 
are owed compensation. In the case of other goods that ought to be distributed fairly, but which we cannot distribute fairly, we think compensation is the way of realising distributive justice. And indeed, some philosophers do contemplate the possibility of, and recommend, compensation of people unjustly deprived of love. Philippe van Parijs (1995) argued that we should compensate individuals unable to find spouses in what I take to be an attempt to recognise the non-instrumental good of long-lasting loving relationships and its import on matters of distributive justice. If love has the kind of importance I assume it has, adequate compensation for leading a loveless life is unavailable (Gheaus 2009). Whether or not one thinks that compensating people for lack of love is appropriate, the possibility of compensation is not at odds with the claim that love is a matter of justice - to the contrary, it confirms the claim. If enjoyment of love was not a matter of justice in the first place then surely no compensation could be due for the lack of this enjoyment.

The solution I favour is to resist the claim in (3) that all matters of justice are also matters of duty and to embrace the possibility that there can be injustice without perpetrators and without conceivable duties of remedy.

\section{References}

Anderson, Joel and Axel Honneth. 2005. Autonomy, Vulnerability, Recognition, and Justice. In John Christman and Joel Anderson (eds.) Autonomy and the Challenges to Liberalism. New Essays, Cambridge University Press.

Anderson, Elizabeth. 1999. What is the point of equality?, Ethics 109: 387-337.

Benjamin, Jessica. 1988. The Bonds of Love: Psychoanalysis, Feminism und the Problem of Domination, New York: Pantheon.

Brake, Elizabeth. 2011. Is Divorce Promise-Breaking?, Ethical Theory and Moral Practice (14):2339.

Brighouse, Harry and Adam Swift. 2014. Family Values, Princeton University Press.

Cohen, G.A. 2009. Rescuing Justice and Equality. Harvard University Press. 
Cowden, Mhairi. 2012. What's love got to do with it? Why a child does not have a right to be loved, Critical Review of International Social and Political Philosophy, 15(3): 325-345.

Feinberg, Joel. 1973. Social Philosophy. Prentice Hall.

Ferracioli, Luara. 2014. The State's Duty to Ensure that Children Are Loved, Journal of Ethics \& Social Philosophy 8(2).

Frankfurt, Harry, 1999. Necessity, Volition and Love. Cambridge: Cambridge University Press.

Gheaus, Anca. 2009. How much of what matters can we refistribute? Love, Justice and Luck, Hypatia 24(4): 68-90.

Gheaus, Anca. 2013. The feasibility constraint on the concept of justice, Philosophical Quarterly 63(252): 445-464.

Held, Virginia. 1993. Feminist Morality: Transforming Culture, Society and Politics. Chicago: University of Chicago Press.

Hollway, Wendy. 2006. The Subject of care. London and New York: Routledge.

Honneth, Axel. 1992. The Struggle for Recognition: The Moral Grammar of Social Conflicts, Cambridge, MA:MIT Pres.

Kant, Immanuel. 1964. Groundwork of the Metaphysic of Morals, trans. H. J. Paton. New York:Harper\&Row.

Kant, Immanuel. 1996. The Metaphysics of Morals, trans. Mary Gregor, Cambridge:Cambridge University Press.

Landau, Iddo. 2004. An argument for marriage”. Philosophy 79:475-481.

Lanzenby, Hugh. 2010. One kiss to many? Giving, luck egalitarianism and other-affecting choice, Journal of Political Philosophy 18(3):271-286.

Liao, Matthew. 2015. The Right to Be Loved. Oxford University Press.

Liao, Matthew. 2006. The Right of Children to Be Loved, The Journal of Political Philosophy 14(4):420-440. 
Lynch, Kathleen, John Baker, Maureen Lyons et al. 2009. Affective Equality: Love, Care and Injustice. Basingstone: Palgrave Macmillan.

Nussbaum, Martha. 2006. Frontiers of Justice: Disability, Nationality and Species Membership. Cambridge, Massachusetts: Harvard University Press.

Nyholm, Sven. 2015. Love Troubles: Human Attachment and Biomedical Enhancements, Journal for Applied Philosophy 32(2):190-202.

Pettit, Philip. 2015. The Robust Demands of the Good, Oxford: Oxford University Press.

Rainbolt, George. 2016. S. Matthew Liao The Right to Be Loved, Notre Dame Philosophical Review https://ndpr.nd.edu/news/64561-the-right-to-be-loved/

Rawls, John, 1972. A Theory of Justice, Oxford: Oxford University Press.

Richards, Norvin. 2010. The Ethics of Parenthood. Oxford: Oxford University Press.

Ruddick, Sara. 1989. Maternal Thinking, Beacon Press.

Singer, Irving. 1994. The Pursuit of Love. Baltimore, MD: Johns Hopkins University Press.

Stocker, Michael. 1976. The Schizophrenia of Modern Ethical Theories, The Journal of Philosophy 73.

van Parijs, Philippe. 1995. Real freedom for all: what (if anything) can justify capitalism? Oxford: Clarendon Press.

Velleman, David. 1999. Love as a Moral Emotion, Ethics 109:338-74.

Wiggins, David. 1998, Needs, Values, Truth. Oxford: Clarendon Press.

Williams, Bernard. 1981. Persons, Character and Morality in Moral Luck. Cambridge: Cambridge University Press.

Wolff, Jonathan and Avner De-Shalit. 2007. Disadvantage. Oxford: Oxford University Press. Young, Iris Marion. 1988. Five faces of oppression, The Philosophical Forum, XIX(4):270-290. 
i I am grateful, for useful feedback on predecessors this paper, to Monika Betzler, the late Jerry Cohen, Andre Grahle, Lisa Herzog, Tim Meijers, Serena Olsaretti, Shanna Slank, Adam Swift, Laura Valentini, audiences at numerous conferences and two referees and an editor of the Canadian Journal of Philosophy. This project has received funding from the Ramon y Cajal Programme from the Spanish Government and from the European Research Council (ERC) under the European Union's Horizon 2020 Research and Innovation programme (Grant Agreement Number: 648610).

ii Here "need" is the same as "morally significant interest". I use the former because most of this paper is about emotional and relational goods, to which we usually refer in terms of needs rather than interests - especially when we speak about tokens rather than types of goods.

iii Which may include facts about the relational history between lover and beloved.

iv The two have at least a strong empirical connection; depending on the definition of love, the connection may be conceptual. I assume a simplified model of love that includes an ability to reciprocate, and that there is some truth to the aphorism attributed to Camus that "There is only misfortune in not being loved; there is misery in not loving.” I am thankful to a referee for drawing my attention to this aphorism.

$v \quad$ Wiggins is not alone in defining needs in this way; see also Feinberg $(1973,111)$ : "In a general sense to say that $S$ needs X is to say simply that if he doesn't have X he will be harmed” and Frankfurt (1999, 163): "To assert that a person needs something means just that he will be inevitably harmed in one way or another - he will suffer some injury or loss - unless he has it”.

vi I am grateful to an editor of this journal for encouraging me to elaborate on this point.

vii Basic moral intuitions here can be divided. Some will see no injustice when individuals' need for love is frustrated out of their own fault. Think, for instance, of Dickens' character Scrooge (before his moral reformation) from $A$ Christmas Carol: Scrooge's life is wrecked because it is entirely devoid of love, and yet he elicits little sympathy, because he seems responsible for his predicament. At the same time, it is not counter-intuitive to say that being the kind of person that Scrooge is represents such a great misfortune that no one deserves its hardships.

viii See also Kant $(1964,67)$.

ix Spontaneous partiality seems to be constitutive to our understanding of love. This of course does not mean that love requires, and even less that it legitimises, any kind of partial behaviour. Partiality as an expression of love can and should be curbed by other desiderata. Note however that there are kinds of spontaneous partiality which are not under the agent's control and which can be very important to the well-being of those who are the recipients of it: selective attention is one example.

$x \quad$ It is, of course, possible to love another in the sense of love defended here while at the same time adhering to duty in the expression of that love.

xi I argue that holding on to an ideal of justice that is immune to feasibility constraints can help justify and motivate efforts to expand our feasibility horizon in Gheaus (2013). 